year]. URL : https://www.ukrinform.ua/rubric-society/2563197-inozemci-v-ukraini-skoili-ponad-52tisaci-pravoporusen-zpocatku-roku-abroskin.html. [In Ukr.]

11. Pohirshennya mihratsiynoho klimatu v Ukrayini mozhe zahostryuvatysya cherez superechnosti mizh Trampom i Merkel' [The deterioration of the migration climate in Ukraine may be exacerbated by the controversy between Trump and Merkel]. URL: https://ua.112.ua/polityka/pohirshenniamihratsiinoho-klimatu-v-ukraini-mozhezahostriuvatysia-cherez-superechnosti-mizh-trampom-i-merkelekspert-454. [In Ukr.]

\title{
Summary
}

The article deals with the organizational and legal aspects of the activity of the State Migration Service as a subject of combating illegal migration, and identifies the main factors that hinder this area. Suggestions for improving such activities were also provided.

Keywords: state migration service, illegal migration, migrant, foreigner, stateless person.

UDC 342.95

DOI 10.31733/2078-3566-2019-5-127-133

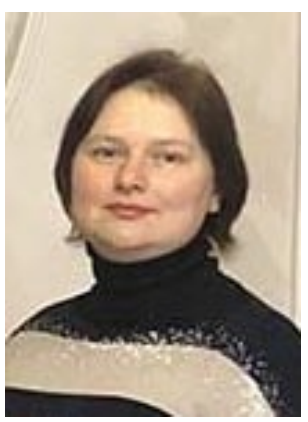

Liliya TIMCHENKO ${ }^{\odot}$

Lecturer

(Dnipropetrovsk State University of Internal Affairs)

\section{EUROPEAN INTEGRATION DIRECTIONS TO IMPROVE THE SYSTEM OF PROVIDING ADMINISTRATIVE SERVICES}

ЛіЛіЯ ТИМЧеНКО. ЄВРОІНТЕГРАЦІЙНІ НАПРЯМИ УДОСКОНАЛЕННЯ СИСТЕМИ

НАДАННЯ АДМІНІСТРАТИВНИХ ПОСЛУГ. СтатТя присвячено аналізу законодавства Європейського Союзу щодо забезпечення якісних, доступних, професійних послуг органів влади населенню цих країн. Автор зазначає, що сектор послуг $є$ настільки важливим в Європейському Союзі, що їх належне забезпечення регулюється первинним і вторинним законодавством, зокрема статями Договору про заснування Свропейського Союзу та Договору про функціонування Європейського Союзу, окремого Протоколу до нього, а також кількома Директивами, прецедентним правом, Хартією засадничих прав Європейського Союзу.

Значну роль у регулюванні сфери послуг відіграв Суд $\mathrm{CC}$, який кілька разів виносив рішення по послугах загальноекономічного інтересу. Рішення Суду ЄС забезпечують основу для визначення загальноекономічного інтересу на національному рівні. Однак кожне рішення досягається на індивідуальній основі, з урахуванням умов і національних особливостей державчленів. Автор звертає увагу, що 6 вересня 2001 р. Свропейський Парламент схвалив резолюцію про затвердження Європейського кодексу належної адміністративної поведінки. Зазначений документ, ухвалений з певними змінами на основі проекту Омбудсмана СС, хоча і не $\epsilon$ формально обов'язковим, проте користується значною повагою і авторитетом. Він справив значний вплив на законодавство і практику публічної служби в країнах СС, а також став основою прийняття етичних кодексів поведінки службовців окремих інституцій Союзу.

Основні принципи надання адміністративних послуг у країнах ЄС лягли у основу законодавчого каркасу взаємодії органів місцевої влади та населення й забезпечили вектори відносин у сфері надання таких послуг, які мають специфічні правові форми діяльності місцевої влади. Автор робить висновок, що у значній кількості країн $\mathrm{CC} \mathrm{та} \mathrm{у} \mathrm{Великій} \mathrm{Британії}$ адміністративні послуги надаються в основному органами місцевого самоврядування. У той же час ключовим механізмом стимулювання підвищення якості надання адміністративних послуг населенню виступає диверсифікована система незалежної оцінки якості таких послуг, що необхідно впровадити й в Україні.

Ключові слова: публічні, адміністративні, мунічипальні та державні послуги; державне управління; органи державної влади; органи місиевого самоврядування.

Problem statement. The social policy of the state is based on the communication of the state authorities and the population in order to ensure decent social standards in the country. This policy is quite diverse, but the key role in public administration is played by the provision

(C) Timchenko L., 2019

https://orcid.org/0000-0003-2696-0272

k_cpd@dduvs.in.ua 
of administrative services by state executive administrations, which at the territorial level provide communication between the state and the population.

With the final approval in Ukraine of the course on European integration, a necessary task of the Ukrainian authorities is to attract effective models of administrative services in the public administration system, such as the European Union countries.

Analisys of publications that started solving this problem. The following national scientists have made an active contribution to the development of the theory of standards of administrative services: V.Tymoschuk, Yu. Danshina, O. Babinova, I. Dragan, O. Zagorulya, V.A. Zanfirov, A.V. Kirmach, O. Skorokhod, O. Vlasenko, T. Burenko, and L. Sheremetyeva.

The article's objective is the analysis of European models of administrative services.

Basic content. The service sector is so important in the European Union that its proper provision is governed by primary and secondary legislation, in particular the articles of the Treaty establishing the European Union and the Treaty on the Functioning of the European Union, a separate Protocol thereto, as well as several Directives, case law, The Union.

In particular, the Treaty on the Functioning of the European Union underlines the importance of services that meet the common human needs. In Art. 14 of the Treaty clearly states that the Council and Parliament establish legal principles for the provision of public services. These principles should be determined by the ordinary legislative procedure, which in the European Union means the submission of a proposal by the European Commission, its adoption by the Council and Parliament [Treaty] [10].

Protocol 26 to the Treaty creates a transparent, reliable and sound basis for the provision of a wide range of services of general public interest, including economic and non-economic services. Protocol 26 states that the Treaty on European Union and the Treaty on the Functioning of the European Union in no way infringe the competence of the Member States to authorize third parties to provide and organize non-economic services providing general needs [11].

Art. 50 (1) of the Treaty defines the concepts of services which are usually provided for remuneration to the extent that they are not covered by the provisions on the free movement of goods, capital and persons. In Art. 50 (2) of the Contract shall specify the types of activities related to services, in particular: industrial, commercial, craft and professional activities. Services are usually provided on a fee basis, but in some cases may be provided free of charge.

Basically providing a service means an activity that is profitable or otherwise beneficial, and is paid, as a rule, from private sources, although not necessarily by the person requesting the service. For example, education in state-funded educational institutions is not a service under the provisions of the Treaty on the Functioning of the European Union, but health insurance under the law of the country in which the service was provided is considered a service [11].

A prerequisite for the exchange of services to fall under the jurisdiction of the Union is the existence of a border crossing of a Member State of the European Union. A common policy on the legal regulation of certain sectors of the service sector is based on separate regulations.

These include: six Directives (2002/77 / EC, 2002/58 / EC, 2002/22 / EU, 2002/21 / EU, 2002/20 / EU, 2002/19 / EU) and one telecommunications decision; Electricity Directive (2003/54 / EC), Gas Directive (2003/55 / EC), Postal Directive (97/67 / EC), White Paper on services of general economic interest (COM (2004) 374), Commission Notice on State -Private partnership [16].

The Court of Justice has played a significant role in regulating the services sector, which has ruled on services of general economic interest several times. The decisions of the Court of Justice provide the basis for determining national economic interest at national level. However, each decision is reached on an individual basis, taking into account the conditions and national characteristics of the Member States.

A significant role in the area of services of common interest was played by the judgment of the Court of Justice of 24 July 2003 in Case C-280/00 Altmark Trans, which lays down four cumulative conditions governing the granting of state compensation for services as non-State aid [12]. The researchers note that there are several legal instruments of the European Union in the field of public services provision and regulation: the Treaty on the Functioning of the EU through ordinary legislative procedures, the Protocols setting out the principles and mechanisms for ensuring the use of services, directives, decisions of the Court of Justice, and the Charter of Fundamental Rights, which sets out clear legal principles that guarantee access to services of general economic interest as a fundamental right.

Art. 14 of the Treaty on the Functioning of the EU and Protocol No. 26 "Services" of the Treaty puts forward three basic requirements for supranational authorities and Member 
States: ensuring a high level of quality of services, their security and accessibility, equal treatment and promotion of universal access and consumer rights [11].

According to Art. 41 of the Charter of Fundamental Rights of the European Union [13], every person has the right to good administration, that is to say, that the institutions, bodies, services and agencies of the Union consider their case impartially, fairly and within a reasonable time. This right includes, first, the right to be heard before any individual measures are taken, and secondly, the right of everyone to have access to his or her personal affairs with due regard for the legitimate interests of confidentiality, professional and commercial secrecy, thirdly, it is the duty of the administration to substantiate its decisions.

In addition, according to Art. 43 of the Charter, every citizen of the Union, any natural or legal person residing or having its legal address in the territory of a Member State, has the right to apply to the European Ombudsman in cases of maladministration in the activities of Union institutions, bodies, services or agencies, with the exception of the Court of Justice of the European Union. while performing their judicial functions [3].

For the most effective implementation of the said provisions, on 6 September 2001 the European Parliament approved a resolution approving the European Code of Good Administrative Behavior (the Code) [17]. This document, approved with some modifications on the basis of the EU Ombudsman's draft, although not formally binding, is highly respected and respected. It has had a significant impact on the law and practice of public service in EU countries [7] and has become the basis for the adoption of codes of conduct for officials of individual Union institutions, in particular the European Commission [14, p. 37]. In addition, a violation of any of its provisions by an employee or agency under Art. 43 of the Charter and Art. 26 of the Code may be the subject of a complaint to the EU Ombudsman. In turn, the Ombudsman's finding in accordance with para. 2 h. 1 tbsp. 228 of the Treaty on the Functioning of the European Union [15] of unsatisfactory governance entails further consideration of the issue by EU institutions, services, bodies or agencies, as well as by the European Parliament and may have significant adverse effects for both Union institutions and specific employees.

As stated by V.M. Zavgorodnya, the Code, laying down principles and standards of conduct, is a benchmark for European institutions and officials in relations with citizens and legal entities. On the other hand, the provisions it provides are an important tool for the Ombudsman in the exercise of his human rights functions. In addition, the Code also matters to citizens and legal entities, since it reveals, in more detail than the Charter of Fundamental Rights of the European Union, the right to good administration [3].

Based on regulatory certainty, the classification of the basic European principles of administrative law in the sphere of relations between public administration bodies and citizens developed by the Council of Europe experts (hereinafter - the Council of Europe), presented in the Council of Europe Handbook "Administration and You" (1996). ), which provides for the separation of two main groups of principles of relations between public administration bodies and citizens:

1) substantive principles, among which there are 7 basic principles: legality, equality before the law, compliance with statutory goals, proportionality, objectivity and impartiality; protection of trust in law and statutory rights and responsibilities;

2) procedural principles, which are divided into 6 basic ones: the principle of access to state (public) services, the right to be heard, the right to representation and assistance, a reasonable term (deadline), notification, explanation of the reasons and determination of remedies and appeals, execution of administrative solutions[11].

According to the researchers, the criterion for ensuring the realization of human rights and freedoms is based on the selection of these groups, for which groups of principles are allocated, which respectively ensure: 1) legal certainty and the rule of law;2) accessibility and openness of public authorities to citizens; 3) liability of the legal entities; 4) control and supervision over the activities of the designated entities in order to ensure the most effective realization of citizens' rights and freedoms.

Objectively, it is advisable to allocate substantive and procedural principles to regulate relations between public administration bodies and citizens, which allows them to more clearly understand their content and application features. At the same time, it should be noted that today the latest classification should be refined and expanded in the light of recent studies conducted under the auspices of the $\mathrm{CoE}$ and the EU aimed at creating a Model Code of Good Administration [2].

On the basis of the principles that determine the principles of activity of public authori- 
ties in European countries, the general scope of European principles of administrative law distinguishes the principles of good administration, which in national literature are mistakenly referred to as the principles of "good governance".

Discussions on the subject available in the national literature are resolved by analyzing the list and content of the principles belonging to this classification attribute to the European principles of administrative law, namely: the content of the mentioned principles mainly relates to the activities of public administration bodies in relations with citizens, so we can speak of " procedural nature of the principles of good administration.

Regarding the list of principles of good administration, according to the results of the CoE study, the principles of good administration in the Member States include: legality, nondiscrimination, proportionality, prohibition of abuse of power, impartiality and objectivity, respect for legitimate expectations, advice and information, respect for justice, use of plain, intelligible, language-friendly, notification of receipt and appointment of an authorized officer, obligation to hand over to competent authority of authorized institution, right to be heard and make statements, reasonable time for making administrative decisions, obligation to state reasons for administrative decisions, indicate ways of protection, notice of decision, protection of information (information) - privacy, requests information retrieval - confidentiality, request for public access to documents, storage of necessary information (records), legal certainty and protection of violated rights, right of access give to appeal an administrative decision, accessibility of administrative bodies and public services, e-government, flexibility in practical work of administrative bodies, efficiency (continuity of providing administrative services, performing administrative work in an efficient way), transparency of administrative actions, access to information (right of personal access to files (information), general right access to documents, right to written materials), understandability (simplicity) (understandable (simple) organization of administration, understandable (simple) coordination of procedures, with simplification of administrative procedures and documents, principle of reducing the number of documents required), principle to act properly, care, improvement of internal rules of administration, support, protection and preservation of public property, training (training) of civil servants, fulfillment of budgetary requirements, rationalization of organization of administration [4, p. 27].

It is necessary to distinguish from the principles of good administration the principles of good governance [6], which are the generic category of principles of good administration, more precisely the latter are one of the standards of good governance.

In general, the basic standards of good governance include: good legislation; legality; participation; transparency of the decision-making process; access to information; proper administration; proper staff; sound financial and budgetary management; efficiency; responsibility and oversight [6].

Thus, the basic principles of administrative services in EU countries formed the basis of the legislative framework of interaction between local authorities and the population and provided vectors of relations in the field of providing such services that have specific legal forms of local government activity.

One of the legal forms of activity of local authorities [2] is their cooperation in providing administrative services to the local population. The fact is that the application of the concept of cooperation of local authorities in other countries takes into account one of the common principles of public policy, namely: the orientation of the authorities to the needs of the local community through the provision of quality services [8, p. 43].

The state, for its part, becomes a partner and guarantor of a favorable environment for the cooperation of local authorities: creates a stable legal framework, allocates funds for partnership and cooperation programs, provides tax benefits and technical assistance for the creation of cooperation projects, etc.

For example, in France, following the adoption of a law by Parliament that gave local governments greater autonomy - as a result, government cooperation arrangements were adopted and the frequency of such cooperation increased to improve the service delivery process for local populations [15].

In order to create effective conditions for cooperation between local authorities, cooperation agreements are concluded, the main elements of which are: the purpose, responsibilities and responsibilities of partners, rules of operation of governing bodies, financial procedures, conditions for accepting new partners (through voluntary membership), arbitration, supervision , procedure for changes to the agreement, etc.

Under the terms of such an agreement, local authorities have the legal right to make 
their own decisions regarding the content of the co-operation agreement and are also responsible for the administrative, operational and financial aspects of providing services to the local population.

Also, the key provisions contained in the cooperation agreement must include a monitoring and evaluation mechanism. It is a matter of legal and financial control over the content of the agreement, which is carried out by both state bodies and associations of local authorities [4, p. 50]. In terms of the financial aspect, services may be charged directly to citizens for permits, licenses and other documents, as well as through contributions from the budgets of local communities participating in the cooperation agreements [9, p. 44].

In different EU countries, the peculiarities of the functioning of representative bodies in the field of providing services to the population largely determine the level of democracy in the country, the creation of real conditions to ensure a decent life of the individual, protect his social and economic rights, the ability of the political system to respond adequately to changes in society.

In Germany, there is a law on administrative procedure governing the external activities of public authorities aimed at verifying the prerequisites, preparing and adopting an administrative act or concluding a public law contract [16]. At the same time, in Finland there is a clear legal basis for the provision of administrative services and their payment: the constitution, the normative documents of the parliament and the ministries. The Parliamentary Act "On Collection of Payments from Public Service Users" gives the government the power to charge for services in accordance with general principles. Paid services are provided by a private organization on a commercial basis when the provision of the service facilitates the commercial activities of the recipient of the service. Compulsory services - free of charge, provided at cost [17].

In Poland [9, p. 45] relations in public administration bodies are regulated by the Code of Administrative Proceedings on matters within the competence of the respective state bodies; in matters of resolution of competence disputes between bodies of territorial self-government units and bodies of government administration; on matters of issue.

The Law on Public Benefits and Volunteering provides for the possibility of outsourcing certain public tasks (together with appropriate funding) to NGOs on a competitive basis [9, p. 49].

Analyzing the experience of European countries on legislative regulation of the process of providing administrative services to the population by local self-government bodies, O.P. Skorokhod notes that in most of these countries, codified acts are effectively in place, dedicated to the detailed regulation of procedures for the activities of local authorities in relation to their relationships with individuals and legal entities.

In particular, there are laws on administrative procedure in Estonia, in Austria - the General Law on Administrative Procedure, in Poland - the Code of Administrative Procedure [8, p. 43].

A characteristic feature of the new EU member states such as Latvia, Poland, Czech Republic, Hungary is the provision of the Laws on Local Authorities, which stipulates that local self-government bodies are able to independently resolve issues of local importance, in particular - to meet the needs of the population by organizing and financing municipal services.

The role of councils in ensuring the quality of public service delivery is key. The basis here will be local public service agreements that aim to strengthen councils for the provision of services to local communities.

To this end, national indicators for evaluating the work of councils have been created, which include: setting priorities and standards, agreeing with the local executive authority; the criteria for evaluating the performance of the councils of their functions (the councils are divided into 4 groups on quality of service delivery): highly effective, higher than average, lower than average, low effective; clear and concise public information that enables citizens to evaluate their activities; smoothness and validity of prices for services that will help them to improve; control by the audit committee in order to prevent deterioration in the activities of the service board, etc [1, p. 158].

Openness in the provision of administrative services, which is also a feature of other countries with their transparency of administrative procedures for the realization of citizens' rights [1, p. 137], is manifested in the availability of information necessary for obtaining administrative services, as well as in the possibility of obtaining consultative assistance from representatives of local authorities.

Conclusions. In a large number of EU countries and in the UK, administrative services are mainly provided by local governments. At the same time, a diversified system of independent evaluation of the quality of such services, which should be implemented in Ukraine, is a 
key mechanism for stimulating the improvement of the quality of administrative services. The need to introduce public control over the quality of administrative services provision in Ukraine is due, first of all, to the representation of the executive authorities on the needs of the population, as well as the need to control the quality of work of the entities providing administrative services to taxpayers as the main consumers of such services. Changing the paradigm of power-to-population relations in the context of European integration causes constant monitoring of the quality of administrative services provision as the main impetus for the modernization of this important mechanism of public administration in the current conditions of state formation in Ukraine.

\section{References}

1. Адміністративна процедура та адміністративні послуги. Зарубіжний досвід і пропозиції для України / авт.-упоряд. В. П. Тимощук. Київ : Факт, 2003. 496 с.

2. Європейські принципи адмінправа: погляд у майбутнє. Правовий тиждень. URL : http://legalweekly.com.ua/index.php?id=16061\&show=news\&\&newsid=120626

3. Завгородня В. М. Стандарти функціонування цивільної служби Свропейського Союзу в європейському Кодексі належної адміністративної поведінки. URL : https://essuir.sumdu.edu.ua/bitstream/123456789/51995/6/Zavhorodnia_Standarty_funktsionuvannia_tsy vilnoi_sluzhby.pdf

4. Загальні аспекти організації надання адміністратив них послуг: навч.-метод. матеріали / О. І. Васильєва, Н. В. Васильєва, О. С. Ігнатенко та ін. Київ : НАДУ, 2012. 56 с.

5. Конституційні акти Європейського Союзу (в редакції Лісабонського договору) / пер. Г. Друзенка та С. Друзенко ; за заг. ред. Г. Друзенка. Київ : К.І.С., 2010. С. 80, 97-101, 389.

6. Корженко В. В., Нікітін В. В. Методологічні та евристичні інтенції сучасної концепції «Governance». URL : www.nbuv.gov.ua/e-journals/DeBu/2006-1/doc/1/01.pdf.

7. Лахижа М. І., Черчатий О. І. Етичні засади в діяльності публічної адміністрації Польщі. Державне будівництво. 2007. № 1. Ч. 2. URL : http://www.kbuapa.kharkov.ua/e-book/db/2007-12/doc/5/05.pdf.

8. Скороход О. П. Надання послуг населенню органами місцевого самоврядування як пріоритет діяльності місцевої громади. Стратегічні пріоритети. №1. 2010. С. 41-46.

9. Токар Л., Гонціяж Я., Новаківська Д. та ін. Адміністративна реформа: досвід Польщі для України: проект «Суспільство відкритих реформ». К. : Генеза, 2000. 52 с.

10. Шереметьева Л. А., Беца І. І. Концептуальні підходи, типи та види державних послуг в Європейському Союзі та в Україні: порівняльний аналіз. URL : http://academy.gov.ua/ej/ej12/txts/10slaupa.pdf

11. Admihistration and You. Principles of Administrativt Law Concernig the Relations Between Administrative Authorities and Private Persons. A Handbook. Council of Europe, Directorate of Legal Affairs, Stasbourg, 1996, P. 72-80. URL: http : // www.csr.ru/ upload/editor files/file0025.pdf.

12. Case law of the Court of Justice of the European Communities and Commission Decisions. URL: http://www.tem.fi/index.phtml?=en\&s=2026.

13. Charter of Fundamental Rights of the European Union (2010/C 83/02) 30.3.2010. URL: http://eur-lex.europa.eu/LexUriServ/LexUriServ.do? uri=OJ:C: 2010:083:0389:0403:en:PDF.

14. Code of Good Administrative Behaviour for Staff of the European Comission in their Relations with the Public. URL: http://ec.europa.eu/transparency/civil_society/code/_docs/code_en.pdf.

15. Joining Forces and Resources for Sustainable Development Cooperation among Municipalities - A Guide for Practitioners. Bratislava: United Nations Development Programme, Bratislava Regional Centre for Europe and the Commonwealth of Independent States, 2006. 81 p.

16. Single market for services (White Paper on Services of General Interest, 'Services' Directive). URL : http://europa.eu/legislation summaries /internal market/single market services/index en.htm
17. The European Code of ${ }^{-}$Good Administrative Behaviour. URL:http://www.ombudsman.europa.eu/en/resources/code.faces.

18. Treaty on the Functioning of the European Union // Consolidated Texts of the EU Treaties as Amended by the Treaty of Lisbon. URL : http://www.official-documents.gov.uk/document/cm73/ 7310/7310.pdf.

1. Administratyvna protsedura ta administratyvni posluhy. Zarubizhnyy dosvid i propozytsiyi dlya Ukrayiny [Administrative procedure and administrative services. Foreign experience and offers for Ukraine] / avt.-uporyad. V. P. Tymoshchuk. Kyyiv : Fakt, 2003. 496 s. [in Ukr.]

2. Yevropeys'ki pryntsypy adminprava: pohlyad u maybutnye [European principles of administrative law: looking to the future]. Pravovyy tyzhden'. URL

http://legalweekly.com.ua/index.php?id=16061\&show=news\&\&newsid=120626. [in Ukr.]

3. Zavhorodnya, V. M. Standarty funktsionuvannya tsyvil'noyi sluzhby Yevropeys'koho Soyuzu v yevropeys'komu Kodeksi nalezhnoyi administratyvnoyi povedinky [Standards of Functioning of the European Union Civil Service in the European Code of Good Administrative Behavior]. URL : https://essuir.sumdu.edu.ua/bitstream/123456789/51995/6/Zavhorodnia_Standarty_funktsionuvannia_tsy vilnoi_sluzhby.pdf. [in Ukr.] 
4. Zahal'ni aspekty orhanizatsiyi nadannya administratyv nykh posluh [General aspects of the organization of the provision of administrative services]: navch.-metod. materialy / O. I. Vasyl'yeva, N. V. Vasyl'yeva, O. S. Ihnatenko ta in. [] Kyyiv : NADU, 2012. 56 s. [in Ukr.]

5. Konstytutsiyni akty Yevropeys'koho Soyuzu (v redaktsiyi Lisabons'koho dohovoru) [Constitutional acts of the European Union (as revised by the Treaty of Lisbon)]/ per. H. Druzenka ta S. Druzenko ; za zah. red. H. Druzenka. Kyyiv : K.I.S., 2010. S. 80, 97-101, 389. [in Ukr.]

6. Korzhenko V. V., Nikitin V. V. Metodolohichni ta evrystychni intentsiyi suchasnoyi kontseptsiyi «Governance» [Methodological and heuristic intentions of the modern concept of "Governance"]. URL : www.nbuv.gov.ua/e-journals/DeBu/2006-1/doc/1/01.pdf. [in Ukr.]

7. Lakhyzha, M. I., Cherchatyy, O. I. (2007) Etychni zasady v diyal'nosti publichnoyi administratsiyi Pol'shchi [Ethical foundations in the activities of the public administration of Poland]. Derzhavne budivnytstvo. № 1. Ch. 2. URL : http://www.kbuapa.kharkov.ua/e-book/db/2007-12/doc/5/05.pdf. [in Ukr.]

8. Skorokhod, O. P. (2010) Nadannya posluh naselennyu orhanamy mistsevoho samovryaduvannya yak priorytet diyal'nosti mistsevoyi hromady [Provision of services to the population by local self-government bodies as a priority of local community activity]. Stratehichni priorytety. №1. S. 41-46. [in Ukr.]

9. Tokar, L., Hontsiyazh, Ya., Novakivs'ka D. ta in. (2000) Administratyvna reforma: dosvid Pol'shchi dlya Ukrayiny: proekt «Suspil'stvo vidkrytykh reform» [Administrative Reform: Poland's Experience for Ukraine: The Open Reform Society Project]. K. : Heneza, 52 s. [in Ukr.]

10. Sheremet'eva L. A., Betsa I. I. Kontseptual'ni pidkhody, typy ta vydy derzhavnykh posluh v Yevropeys'komu Soyuzi ta v Ukrayini: porivnyal'nyy analiz [Administrative Reform: Poland's Experience for Ukraine: The Open Reform Society Project]. URL : http://academy.gov.ua/ej/ej12/txts/10slaupa.pdf. [in Ukr.]

11. Admihistration and You. Principles of Administrativt Law Concernig the Relations Between Administrative Authorities and Private Persons. A Handbook. Council of Europe, Directorate of Legal Affairs, Stasbourg, 1996, P. 72-80. URL: http : // www.csr.ru/ upload/editor files/file0025.pdf. [in Eng.]

12. Case law of the Court of Justice of the European Communities and Commission Decisions. URL: http://www.tem.fi/index.phtml?=en\&s=2026. [in Eng.]

13. Charter of Fundamental Rights of the European Union (2010/C 83/02) 30.3.2010. URL: http://eur-lex.europa.eu/LexUriServ/LexUriServ.do? uri=OJ:C: 2010:083:0389:0403:en:PDF. [in Eng.]

14. Code of Good Administrative Behaviour for Staff of the European Comission in their Relations with the Public. URL: http://ec.europa.eu/transparency/civil_society/code/_docs/code_en.pdf. [in Eng.]

15. Joining Forces and Resources for Sustainable Development Cooperation among Municipalities - A Guide for Practitioners. Bratislava: United Nations Development Programme, Bratislava Regional Centre for Europe and the Commonwealth of Independent States, 2006. 81 r. [in Eng.]

16. Single market for services (White Paper on Services of General Interest, 'Services' Directive). URL : http://europa.eu/legislation_summaries/internal_market/single_market_services/index_en.htm. [in Eng.]

17. The European Code of ${ }^{-}{ }^{-}$Administrative Behaviour. URL:http://www.ombudsman.europa.eu/en/resources/code.faces. [in Eng.]

18. Treaty on the Functioning of the European Union // Consolidated Texts of the EU Treaties as Amended by the Treaty of Lisbon. URL : http://www.official-documents.gov.uk/document/cm73/ 7310/7310.pdf. [in Eng.]

\section{Summary}

The article deals with the analysis of European Union legislation on the provision of quality, accessible, professional services of the authorities to the population of these countries. The author notes that the services sector is so important in the European Union that its proper provision is governed by primary and secondary legislation, in particular the articles of the Treaty establishing the European Union and the Treaty on the Functioning of the European Union, a separate Protocol thereto, as well as several Directives, precedent, Charter of Fundamental Rights of the European Union. The Court of Justice has played a significant role in regulating the services sector, which has ruled on services of general economic interest several times. The decisions of the Court of Justice provide the basis for determining national economic interest at national level. However, each decision is reached on an individual basis, taking into account the conditions and national characteristics of the Member States. The author notes that on 6 September 2001 the European Parliament approved a resolution approving the European Code of Good Administrative Behavior. This document, approved with some modifications on the basis of the EU Ombudsman's draft, although not formally binding, is highly respected and respected. It has had a significant impact on the law and practice of public service in EU countries and has become the basis for the adoption of codes of conduct for officials of individual Union institutions. The basic principles for the provision of administrative services in EU countries formed the basis of the legislative framework for the interaction between local authorities and the population and provided vectors of relations in the area of providing such services that have specific legal forms of local government activity. The author concludes that in a large number of EU countries and in the UK, administrative services are mainly provided by local governments. At the same time, a diversified system of independent evaluation of the quality of such services, which should be implemented in Ukraine, is a key mechanism for stimulating the improvement of the quality of administrative services.

Keywords: public, administrative, municipal, public services; public administration; public authorities; local self-government. 